\title{
Visual Merchandising Displays: Wasted Effort Or Strategic Move? The Dilemma Faced By Apparel Retail Stores
}

M. C. Cant, PhD., University of South Africa, South Africa Mrs Y. Hefer, University of South Africa, South Africa

\begin{abstract}
Retailing per se has been with us since the beginning of time. Over the years retailing methods and techniques have been adapted and changed in order to meet the demands of the market. In the same way the in store activities aimed at the consumer has been evolving and changing. At first the focus was on merchandising per se, but even merchandising has become more focussed and professional and specialised. This has led to this study focussing on visual merchandising and its effect - or not - on consumer spending. Much has been said about visual merchandising displays and the effect it has on consumer perceptions. Consumers' perceptions towards visual merchandising displays are investigated and evaluated in this study. The primary research question that was posed in this study was to determine the effect of visual merchandising displays on consumer perceptions. Explorative research was performed and qualitative data were collected by means of focus groups and naïve sketches. The data was analysed by means of a thematic analysis process. The main conclusions that can be drawn from this research is that the perceptions of visual merchandising displays are subliminal in creating an interest and desire to further peruse the merchandise and aesthetically to beautify the store.
\end{abstract}

Keywords: Visual Merchandising Display; Consumer Perceptions; Marketing Stimuli; Apparel; Retail Industry; Retailers

\section{INTRODUCTION}

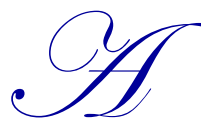

question often asked by apparel retailers is whether the visual merchandising displays used in their store add any value or benefit to the customers experience and value. Retailers want their stores to attract consumers into their stores, assisting them to find the merchandise they desire and to motivate them to make planned, unplanned and impulse purchases and ultimately provide them with an enjoyable shopping experience (Levi \& Weitz, 2009). If these displays do not have this desired effect the question arises if it has any value to spend time and money on these displays.

The visual merchandising displays and the type of environmental stimuli these visual merchandising displays create in apparel retail stores could have an effect on consumers' perceptions, which is the practice where a person observes, selects, organises and reacts to environmental stimuli in a significant way (du Plessis \& Rousseau, 2003). It is therefore important that visual merchandising displays created in an apparel retail stores influence a consumer to approach that store and make a purchase. In the current world wide economic downturn and hardships it has become increasingly important that apparel retailers ascertain how their visual merchandising displays are perceived by consumers. In this way they will be able to ascertain how consumers are actually seeing their product, and how they interpret these products.

This study proceeds from a consumer response centred approach to visual merchandising stimuli, in an attempt to holistically consider this area of the retail industry. The study could benefit apparel retailers as consumers' perceptions towards visual merchandising displays were uncovered. The same findings can realistically be applied to apparel retailers anywhere in the world with some adaption to meet local conditions and customs. 


\section{DISCUSSION}

\section{South African apparel retail industry}

The South African retail industry is a major contributor to the economic development and well being in a country. The fact that large numbers of people are employed in this sector means that it has a serious influence on people's lifestyles.

As the statistics indicate, the retail industry in South Africa is one of the largest contributors to the economy's total income (Statistics South Africa, 2010). The retail industry in South Africa has developed and grown in the past 10 years from 19 million in January 2000 to R47000 million in December 2011. Most of the growth that has taken place has been in the general dealer's category, as well as in the textiles, clothing, and footwear and leather goods categories (apparel industry).

Figure 1 below shows the retail trade sales, at constant 2008 prices, from January 2005 to December 2011.

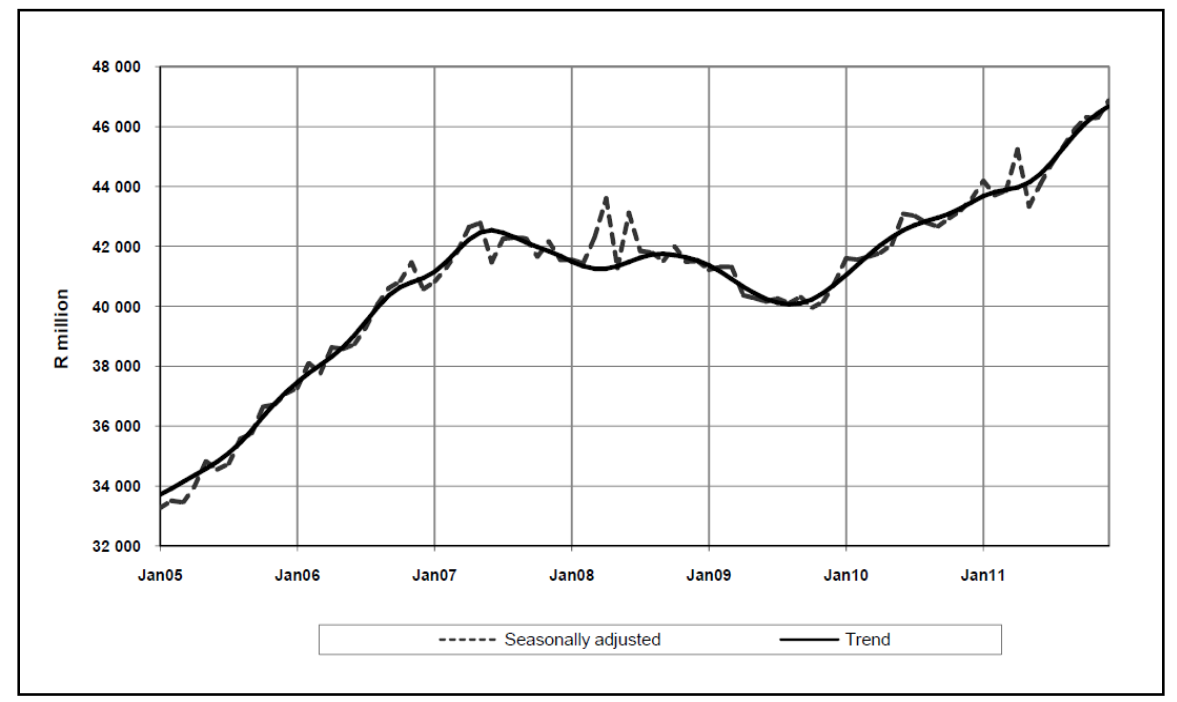

Figure 1: Retail trade sales

Source: Statistics South Africa. 2011. Retail trade sales. Statistical release P6242.1.

December. Pretoria: Statistics South Africa. p. 4.

It can be inferred from the statistics that the apparel retail industry is a significant player in the GDP of the country, and that the apparel retail industry is a major contributor to the overall retail industry growth that bhas taken place in the past ten years (Statistics South Africa, 2011). It is therefore important that the apparel industry keep on looking at ways and means to stay innovative and to generate methods to develop as competition is becoming more and more fierce and intensive.

With the demands placed on consumer's disposable income and the worsening economic climate the competitive environment has changed and consumers are now in a position to be more demanding and selective extending the pressure on retailers.

Due to the above factors prevailing in the apparel retail environment today, every retailer strives to entice consumers to enter their store - and this is done by having the most exciting and visually appealing retail environments. The aim is to create an atmosphere where consumers can shop in a pleasant and visually appealing environment for the colours, fabrics, value and styles they want. In order to achieve such visually appealing retail environments, 1 retailers make use of visual merchandising displays. 


\section{Visual merchandising displays}

Visual merchandising displays are defined as visual features that create attention or pleasure in a store with the aim of enhancing the shopping experience of the customer (Mathew, 2008). These displays are also known as feature areas. In essence these displays or feature areas are used to decorate and beautify a store by adding additional fixtures, props, posters, materials, colours, frills and objects to a store in order to enhance the appeal of the merchandise or products on offer.

The visual merchandising display process is often referred to as the "silent salesperson" by providing the consumers with information through visual mediums as well as by suggestive selling (suggestions to add items to a consumers' original purchase) (Bhalla \& Anuraag, 2010). These visual merchandising displays make use of creative techniques in order to save the sales person's as well as the shopper's time by making shopping easier and faster.

The retail industry has changed significantly over the years and this has posed (and continues to do so) a number of challenges to retailers in the form of visual merchandising displays. New formats translate into new ideas and creativity. For example, Pegler (2010) pointed out that due to the size of super stores and department stores, they need to be "warmed up" by using the correct lighting and display techniques.

Visual merchandising displays are frequently used to introduce new products or brand extensions to consumers as well as to decorate a store. This is a planned and systematic approach to display the stock that is available in the store. According to Bhalla \& Anuraag, (2010) and Pegler, (2010) visual merchandising displays is:

- $\quad$ a tool by which sales are met and targets achieved.

- $\quad$ a method by which to improve the appeal of merchandise on the floor.

- a mechanism to communicate or 'talk' to a consumer and influence his or her decision to purchase a product or service

- $\quad$ used for special occasions and seasons such as mother's day, Easter, or to introduce new arrivals to consumers for a new season such as summer ranges.

- a method of educating the consumers about the product or service in an efficient and imaginative way, for example using lifestyle graphics to inform consumers how products could be worn together.

- to establish an inventive medium to display merchandise in a 3D environment, allowing long lasting impact and recall value.

- to set the company apart from others.

- to establish relationships between fashions, product design and marketing by keeping the product in key focus.

- to combine the creative, technical and operational features of a product and the store.

Visual merchandising displays is used to great effect in retail outlets to perform different functions such as to support sales, to support the retail strategies, to communicate with consumers and to assist in communicating the fashion retailers' brand image (Levi \& Weitz, 2009 and Bell \& Turnus, 2008).

It is the aim of the retailer to use visual merchandise displays to attract customers in the store by means of window displays and then by means of visual merchandising displays to generate or increase sales. Retailers realize that the way in which they use visual merchandising displays has the power to create images about the products in the mind of the consumers - images that will affect future patronage and perceptions of the product and brand. Visual merchandising displays are now a significant tool for retailers in order to attract and entice consumers into their stores.

\section{Consumer perceptions}

The world consumers live in is rich with ambience. When entering an apparel retail store, consumers act differently to the sensations and stimuli around them; they either pay attention to it or ignore it. Each and every message created by an apparel retailer is done with a specific purpose in mind. However consumers transpire to make their own decisions by adapting the message that is created by certain sensations or stimuli (such as visual 
merchandising displays) to fit in with their own unique experiences, desires and prejudices (Cant, Brink \& Brijball, 2006).

A consumer's decision to visit/revisit an apparel retail store can be influenced by the visual merchandising displays. If consumers' perceptions - a process of examination in which the outside world is passed through a filter and only the most significant or appealing things make it through the filter and impact the consumers (Blythe, 2008) - of the visual merchandising displays are positive they can decide to revisit the store; however if they have a negative perception they might not return to the store again. As a result, the retail environment that is created by utilising visual merchandising displays is able to guide consumers' conclusions about the merchandise, the service quality and the consumers' satisfaction of the store.

Levi and Weitz (2009) point out that the consumers' perceptions of a store's environment depend on the consumers' shopping goals. When consumers are shopping for something that they deem as an unfulfilling mission, they prefer to be in a soothing and calming environment; however, if consumers are shopping for pleasure they prefer being in an exciting environment. It can therefore be inferred that consumers' perceptions may have an impact on the way they behave towards a store and its merchandise.

Apparel retailers have to establish how their visual merchandising displays are perceived by the consumers. It is essential to identify what consumers are actually seeing and how they interpret it. By establishing how visual merchandising displays are perceived by the consumers, it could benefit apparel retailers to align the internal focus of their visual merchandising displays with the consumers' expectations.

\section{RESEARCH METHODOLOGY}

The fact that a detailed explanations in terms of consumer perceptions were needed, qualitative research was used in this study as it is research that discovers the true significance and new insights about the available data (Zikmund \& Babin, 2010).

The extent to which visual merchandising displays effect consumers' perceptions was studied by means of exploratory research. Exploratory research is used to observe insights into a common nature of a research problem (Tustin, Ligthelp \& Martins, 2005).

Due to the exploratory nature of the study, non-probability, purposive sampling was used. Non-probability sampling is a sampling method where the samples are grouped in a process that does not give all the individuals in the population an equal chance of being selected (Tustin et al, 2005). Subjects in a non-probability sample are usually selected on the basis of their accessibility or by the purposive personal judgment of the researcher. In purposive sampling, the researcher samples with a purpose in mind (Zikmund \& Babin, 2010).

The inclusion criteria for the purposive sampling for this research study were as follows:

- $\quad$ People who buy clothing at apparel retail outlets in Tshwane

- People who reside in Tshwane

- $\quad$ People who read, speak and understand English

- $\quad$ People who have a cell phone and who have access to e-mail

- People that are willing and that have the time to participate in the study

Data collection was conducted by means of crystallisation. Crystallisation is a post-modernist development of completing research and it is used in order to find various instances from numerous sources to find union (Huberman \& Miles, 1994). Focus groups, which are an unstructured, free flowing interview with a small group of people, usually between six and ten participants (Zikmund \& Babin, 2010), together with naive sketches, which are open-ended questionnaire that asks participants questions relating to a specific study (Hodder, 1994), were used to collect data from 16 participants (eight participants in each focus group). In this way, two forms of data were compared with one another to gain the most data possible from each participant. 
The focus groups were based on the use of visual stimulus material. Photographs were taken of an apparel retail store in Tshwane and they were presented to the participants in the focus groups. The participants were asked questions derived from the research aims. The following questions were used to structure the focus groups (the same questions were also used in the naïve sketches):

1. What do you think about visual merchandising displays?

2. When you walk into a clothing store, what do you notice about the visual merchandising displays?

This research study was contextual in nature, therefore thematic analysis was used to analyse the data. Thematic analysis is an exercise in qualitative research which involves searching through qualitative data to identify any repeated patterns (Tesch, 1990). These patterns are then sorted into themes and categories. It is a process that organises and describes data in detail (Braun \& Clarke, 2006).

\section{RESULTS}

The outcome of the questions asked in the focus groups are examined in terms of two main themes and their underlying categories as outlined by Tesch's model (thematic analysis).

\section{Theme 1: Participants perceived visual merchandising displays as a tool that creates a "purchasing" context that adds to the retail experience.}

The participants expressed that the visual merchandising displays enhanced their buying experience in subliminal ways through the beautifying of the store and by creating a relaxed environment to shop in. They also stated that the displays contributed to the image of a store through the quality of the product sold in store and the character of the store.

They also stated that visual merchandising displays are viewed as a promotional tool, for example: to convey branding, the product, product information and product quality. The participants said that in order for the displays to attract attention they should be well designed. If not, they only create irritation and it could be overbearing.

Four categories emerged from the first theme and are explained below.

- Visual merchandising displays enhance the consumers' buying experience in subliminal ways:

$\circ \quad$ It beautifies the store (including a colourful environment and decorative in nature)

$\circ$ It creates a relaxed environment

- $\quad$ Visual merchandising displays contribute to the image of the store through:

$\circ$ The quality of the product sold

$\circ$ The character of the shop

- Visual merchandising displays are viewed as a promotional tool (for example: branding, product, information and quality).

- Many participants were of the opinion that the visual merchandising displays were part of the store's product promotion strategy. Posters, mannequins, and clothes that are displayed in light boxes seem to affect the consumer, as the focus group explained that they thought that the reason these products were being promoted by these various displays was for the consumer to be enticed to buy them.

- Visual merchandising displays should be well designed to attract positive attention (if not, it creates "irritation" and could be "overbearing").

- The focus groups explained that in order to have a positive experience in a store, the visual merchandising displays should be well designed but should limit the amount of décor that is used in the display. Furthermore, the focus groups explained that when merchandise is moved or scattered regularly because the visual displays change, it causes irritation and negative feelings towards the 
store's ability to satisfy the consumers' needs. Spatial orientation and perfectly designed visual merchandising displays are definitely themes that affect the consumers' perception of the store.

\section{Theme 2: Participants' perceptions of visual merchandising displays varied from person to person with} emphasis on the subliminal nature of visual merchandising displays.

Participants explained that visual merchandising displays are mostly noticed in a subliminal way, and that it is influenced by personal preferences, contextual aspects such as themes, type of store and brand or branding, gender to some degree, and sensory and cognitive aspects.

It appears that although the visual merchandising displays affect the consumers in terms of their total perception of the retail store, they are not completely reliant on the displays to make their purchasing decisions. In fact, if they are specifically shopping for a certain item, they may not even notice the displays unless the product they are searching for is, in fact, part of the display. These are all mentioned in the following paragraphs together with quotes to verify the findings. Below are a few quotes taken from the focus groups to illustrate the participant's views on this objective.

Four categories emerged from the second theme and are explained below:

- $\quad$ Personal preferences

- When consumers are shopping for something that they deem as an unfulfilling mission, they prefer to be in a soothing and calming environment, however, if consumers are shopping for pleasure they prefer being in an exciting environment (Levi \& Weitz, 2009).

- Furthermore, the focus groups propounded the view that the after-purchase satisfaction is what often draws consumers back to a particular retail store, regardless of the visual merchandising displays. If the store fulfilled their shopping goals previously, they are also more likely to return. Similarly, no amount of great quality visual merchandising displays will draw consumers in if they have already decided that a particular store will not aid in fulfilling their shopping goals.

- $\quad$ Contextual aspects such as themes, type of store and brand or branding

- A consumer will often notice a particular theme that is being conveyed through a visual merchandising display, and will appreciate the store's attentiveness to social and environmental phenomena such as sporting events or seasonal changes. The focus groups also explained that they noticed ill-fitting themes in apparel retail stores, in terms of whether the items displayed are actually available in store, or whether it sends the correct message with the complement of the display.

- $\quad$ Gender

$\circ$ The focus groups agreed that there are sharp differences between male and female apparel consumers, in that women are more attentive to the complete retail experience that includes visual merchandising displays. Comparatively, men search for markers in a store about where to find what they are looking for. For example, if a man is shopping for a suit, he searches objectively for visual clues that will point him in the direction of the suit section, not paying too much attention to the style or manner in which the suits are displayed.

- $\quad$ Sensory and cognitive aspects (colour emerged as an important cognitive and sensory stimulus)

- The focus groups commented that colourful visual merchandising displays positively attracted consumer attention. It was also noted that the focus groups were very aware of colour displays that were realistic for the consumer, and not merely part of a fashionable display.

\section{DISCUSSION AND CONCLUSION}

The participant's perceptions of visual merchandising displays were subliminal (intense enough to influence the mental processes or behaviour of the consumer) in creating an interest and desire to further peruse the merchandise and aesthetically to beautify the store. The perceptions of the participants indicated that the visual merchandising displays contributed to the image of the store and also added to the character of the store. Spatial 
orientation and perfectly designed visual merchandising displays are definitely themes that affect the consumers' perception of an apparel retail store.

Furthermore, consumers perceived visual merchandising displays as a tool to establish a 'purchasing' environment and as a vehicle to portray the brand of the store.

What is noticed by the consumers in terms of the visual merchandising displays are mostly below the threshold of consciousness, and it is influenced by personal preferences, contextual aspects such as themes, type of store and brand or branding, gender to some extent, quality of the visual merchandising display and sensory and cognitive aspects.

The research study suggests that women are more attentive to the complete retail experience which includes visual merchandising displays. In comparison, men search for signs in a store about where to find what they are looking for.

The focus groups also explained that they notice ill-fitting themes in apparel retail stores, in terms of whether the items displayed are actually available in store, or whether it sends the correct message with the complement of the display.

\section{AUTHOR INFORMATION}

Professor Michael Cant is CoD of the Department of Marketing and Retail Management at the University of South Africa. He has published over 35 accredited articles in refereed journals and is the editor and author of more than 20 books in marketing. These books are widely prescribed at universities in South Africa. He has presented papers at more than 45 international conferences all over the world and is a well respected marketing and retail scholar. He holds a PhD in Marketing from the University of South Africa. E-mail: cantmc @ unisa.ac.za (Corresponding author)

Mrs Yolandé Hefer is a lecturer in the Department of Marketing and Retail at Unisa. She holds a Consumer Science degree in fashion retailing as well as an Honours degree in Marketing. She has 10 years experience in the retail sector and has worked in one of South Africa's major retail stores as a visual merchandiser. Her research interests include marketing, retail, and merchandising. E-mail: hefery@unisa.ac.za

\section{REFERENCES}

1. Cant, M. C., Brink, A. \& Brijball, S. (2006). Consumer behaviour. Cape Town: Juta.

2. $\quad$ Bell J.\& Ternus, K. (2006). Silent selling. $3^{\text {rd }}$ ed. New York: Fairchild Publications.

3. Bhalla, S. \& Anuraag, S. (2010). Visual merchandising. New Delhi: McGraw Hill.

4. $\quad$ Blythe, J. (2008). Consumer behaviour. London: Thomson.

5. Braun, V. \& Clarke, V. (2006). Using thematic analysis in psychology. Qualitative Research in Psychology, 3: 77-101.

6. du Plessis, P. J. \& Rousseau, G. G. (2003). Buyer behaviour: A multi-cultural approach. $3^{\text {rd }}$ ed. South Africa: Oxford University Press.

7. Hodder, I. (1994). The interpretation of documents and material culture. In Denzin, N. K. \& Lincoln, Y. S. (Eds), Collecting and interpreting qualitative materials (703-716). California: Sage Publications.

8. Huberman, A. M. \& Miles, M.B. (1994). Data management and analysis methods. In Denzin, N. K. \& Lincoln, Y. S. (Eds), Collecting and interpreting qualitative materials (179-210). California: Sage Publications.

9. Levi, E. \& Weitz, S. (2009). Retailing management. $7^{\text {th }}$ ed. New York: McGraw Hill.

10. Mathew, R. (2008). Apparel Merchandising. New Delhi: Book Enclave.

11. Pegler, M. (2010). Visual merchandising and display. $5^{\text {th }}$ ed. China: Fairchild publications.

12. Statistics South Africa. (2010). Mbalo Brief-Educational article on retail trade. [Online] Available from: Statistics South Africa: http://www.statssa.gov.za/newsletters/Mbalo_brief_December_2010.pdf [Accessed: 2011-02-25]. 
13. Statistics South Africa. (2011). Retail trade sales. Statistical release P6242.1. December. Pretoria: Statistics South Africa.

14. Tesch, R. (1990). Qualitative research analysis tapes and software tools. New York: Wordsworth.

15. Tustin, D. H., Ligthelm, A., Martins, J. H. \& Van Wyk, H De J. (2005). Marketing research in practice. South Africa: ABC Press.

16. Zikmund, G. \& Babin, B. J. (2010). Exploring marketing research. $10^{\text {th }}$ ed. China: South Western. 